\title{
The Effect of Surface Roughness on
} Early In Vivo Plaque Colonization on Titanium

\author{
Lia Rimondini, $*$ Silvia Farè, ${ }^{\dagger}$ Eugenio Brambilla, ${ }^{\ddagger}$ Andrea Felloni, ${ }^{\ddagger}$ \\ Claudio Consonni, ${ }^{\dagger}$ Francesco Brossa,${ }^{\S}$ and Antonio Carrassi*
}

THIS STUDY ASSESSES IN VIVO the surface roughness necessary to reduce plaque colonization on titanium after 24 hours. Three groups of 16 titanium disks were assigned to 3 different polishing groups (A, B, and C). The roughness was evaluated with a laser profilometer and the morphology with a scanning electron microscope (SEM). Eight volunteers were enrolled and two stents were applied in the mandibular posterior region of each. Each stent supported 3 disks, one per group. The volunteers suspended oral hygiene for 24 hours, after which the stents were removed; one was processed for evaluation of the adherent biomass and the other for SEM study. On each specimen a global area of $100 \times 125 \mu \mathrm{m}$ was examined with SEM. The area was composed of five $20 \times 25 \mu \mathrm{m}$ randomly selected fields. For each field the density of bacteria and the morphotypes were recorded. The data quoted for the global area are cumulative of those observed in the $20 \times 25 \mu \mathrm{m}$ fields. Group A had a significantly smoother surface than groups B and C. The adherent microbial biomass determination and SEM evaluation revealed that group A contained less bacteria than the roughest group. The bacterial population was composed of cocci in group $\mathrm{A}$, and of cocci and short and long rods in groups $\mathrm{B}$ and $\mathrm{C}$. We conclude that a titanium surface with $\mathrm{Ra} \leq 0.088$ $\mu \mathrm{m}$ and $\mathrm{Rz} \leq 1.027 \mu \mathrm{m}$ strongly inhibits accumulation and maturation of plaque at the 24-hour time period and that such smoothness can be achieved in transgingival and healing implant components. J Periodontol 1997;68:556-562.

Key Words: Dental implants; titanium; dental plaque/microbiology

Several hundred species of bacteria live in the oral cavity as commensals. ${ }^{1}$ Of these only a few strains are observed to invade tissues around natural teeth ${ }^{2}$ and implants ${ }^{3.4}$ and cause their destruction. ${ }^{5}$ A prerequisite for the virulence of bacteria in the oral cavity is their ability to adhere to a surface before colonizing and damaging host tissues. The bacterial colonization process is complex and involves different stages: 1) transportation of bacteria to the surface through the saliva suspension medium; 2) nonspecific electrostatic interaction between bacterial cells and substratum ${ }^{6}$ and/or specific interaction between bacterial adhesions and ligands; ${ }^{7}$ and 3) aggregation among different bacterial species. ${ }^{8}$ The initial interaction between

\footnotetext{
*Department of Oral Pathology and Medicine, School of Dentistry, University of Milan, Milan, Italy

'Department of Applied Cheminstry and Physics, Politecnico di Milano. Department of Restorative and Pediatric Dentistry, School of Dentistry, University of Milan.

${ }^{\S}$ Institute for Advanced Materials, EU Joint Research Centre, Ispra, Varese, Italy.
}

a bacterial cell and the substratum is influenced by the physico-chemical properties of the substratum surface contaminated by salivary or crevicular fluid components.

The first physico-chemical factor of the adhesion process is the surface-free energy. The interfacial-free energy of microbial binding can be computed as a function of the surface-free energies of the substratum, bacteria, and the surface tension of suspension medium. ${ }^{9}$ Surface roughness is the second factor to be considered. The presence of pits and grooves promotes colonization because it shelters bacteria from clearance forces of salivary flow, chewing, swallowing, and hygiene procedures and it allows them to establish less reversible bindings. The influence of surface roughness seems to be particularly important since it overrules the effect of the substratum surface-free energy. ${ }^{10} \mathrm{~A}$ titanium "cell-friendly" surface ${ }^{11}$ is the goal for dental implant osseointegration but it has to be avoided if bacterial cells are involved, since microbial colonization has been shown to be one of the most important causes of implant failure. 


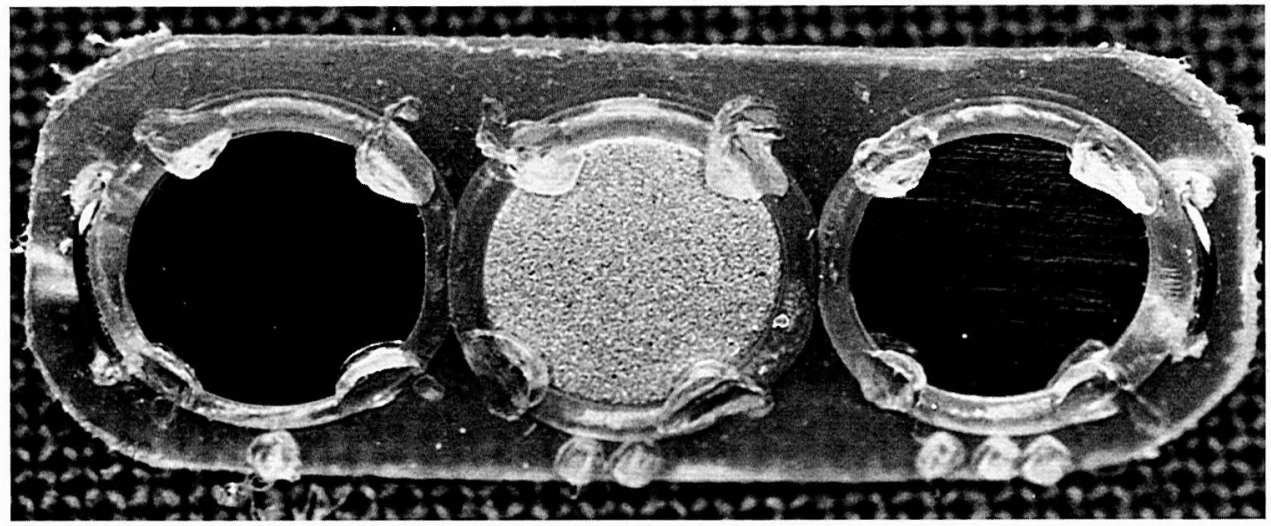

Figure 1. Titanium specimens fixed in the acrylic stent. From left to right group $A, C$, and $B$.

Table 1. Abrasives and Polishing Procedures

\begin{tabular}{llcccc}
\hline $\begin{array}{l}\text { Paper and } \\
\text { Tissue }\end{array}$ & Abrasive & $\begin{array}{c}\text { Grain } \\
\text { Size }(\mu \mathrm{m})\end{array}$ & R.P.M. & $\begin{array}{c}\text { Pressure } \\
(\mathrm{N})\end{array}$ & $\begin{array}{c}\text { Time } \\
(\mathrm{sec})\end{array}$ \\
\hline Grinding paper & SiC & 1000 & 300 & $50-100$ & $30+30$ \\
DP-DUR & Diamond & 6 & 150 & $100-200$ & $30+30$ \\
DP-DUR & Diamond & 3 & 150 & 100 & 30 \\
OP-Chem & $\mathrm{SiO}_{2}$ & 0.04 & 150 & 100 & 60 \\
\hline
\end{tabular}

The purpose of this study was to assess in vivo the optimal polishing level of a titanium finish in order to reduce early plaque colonization.

\section{MATERIALS AND METHODS}

\section{Specimen Preparation}

Forty-eight grade IV pure titanium $4 \mathrm{~mm}$ wide disks, obtained by truncation of a titanium sheet, were used for the study. The disks were embedded, using an inclusion device," in a resin holder ${ }^{\mathbb{I}}$ and equally divided into the following 3 groups of polishing: group A was automatically ${ }^{*}$ polished with grinding paper, tissue (DP-DUR) impregnated with diamond paste $(3 \mu \mathrm{m}$ grain size) and finally with gum tissue (OP-Chem) and a suspension of $\mathrm{SiO}_{2}$ with a grain size of $0.04 \mu \mathrm{m}$; group B was automatically ${ }^{*}$ polished with grinding paper and tissue (DPDUR) impregnated with diamond paste ( $6 \mu \mathrm{m}$ grain size); group C was sandblasted with $200 \mu \mathrm{m}$ diameter corundum at 6 bar pressure for 120 seconds. Table 1 provides details of the papers, abrasives, pressures, and working times used in the surface finishing procedures.

\section{Morphological and Profilometric Analyses}

After polishing, the resin was removed and the specimens were cleaned by an ultrasonic device with tetrahydrofurane for 10 minutes; 10 specimens from each group were randomly selected for profilometric analysis. The profi-

"Primopress, Struers Rodevre, Copenhagen, Denmark.

Transoptic, Buheler, Lake Bluff, IL.

"Abrapol, Struers Rodevre, Copenhagen, Denmark. lometric analysis was performed with a laser profilometer** according to the ISO standard 468/1982. Two perpendicular measurements were performed at the center of each specimen and the $\mathrm{Ra}$ and $\mathrm{Rz}$ values were recorded. The specimens were mounted on an aluminum stub using conductive adhesive tape, ${ }^{t+}$ and the surface morphology was observed with a scanning electron microscope (SEM).

\section{In Vivo Tests}

Sixteen acrylic stents were made. A disk from each group was mechanically fixed by grips on each stent (Fig. 1). Eight volunteers, aged between 20 and 22 years, with good oral health and Löe and Silness plaque index ${ }^{12}$ close to 0 at the beginning of the study, and who had not used antibiotics or chlorhexidine for 2 months before the study were selected. Two acrylic stents were applied to each subject in the left and right lower molar and premolar region by an orthodontic wire ligature. Then the volunteers stopped all hygiene procedures for 24 hours. After 24 hours, the stents were removed. A stent from each subject was immediately processed for SEM observation and the other for microbiologic analysis.

\section{Microbiological Analysis (Biomass Determination)}

The quantitative evaluation of the adherent microbial biomass was performed using a colorimetric technique based on the reduction of tetrazolium salts (MTT). ${ }^{13}$ The procedure was as follows:

Reagents. An MTT solution was prepared by dissolving $5 \mathrm{mg}$ of 3-(4,5) dimethylthiazol-2-yl-2,5 diphenyl tetrazolium bromide ${ }^{\S}$ per $\mathrm{ml}$ of sterile phosphate buffered saline ${ }^{\S}$ A lysing solution was prepared by dissolving $10 \% \mathrm{v} / \mathrm{v}$ of sodium dodecyl sulphate ${ }^{\S \S}$ and $50 \% \mathrm{v} / \mathrm{v}$ of dimethylformamide ${ }^{\S \S}$ in distilled water.

\footnotetext{
**RM 600 Rodenstock, Gottingen, Germany.

"Conductive adhesive tape, Agar Scientific Ltd., Cambridge, UK.

新840A, Jeol, Tokyo, Japan.

Sigma Chemicals, St. Louis, MO.
} 
MTT assay. The specimens were rinsed twice in sterile phosphate buffered saline and each one was placed in a well of a 24-well polystyrene plate.|ll To each well, $1 \mathrm{ml}$ of fresh sterile brain-heart-infusion broth and $100 \mu \mathrm{l}$ of MTT solution were added and the plates were incubated for 3 hours at room temperature in the dark. During incubation, the redox system converts the yellow salt to an intracellular insoluble purple formazan. Formazan crystals obtained were dissolved by addition of $0.5 \mathrm{ml}$ of lysing solution to each well. After an incubation of 3 hours at room temperature, $100 \mu l$ of the suspension of each well was placed in a 96-well plate. 11 Adsorbance (OD) was measured by a dual wavelength spectrophotometer at 620 to $550 \mathrm{~nm}$.\# The mean blank OD for the same 96 well plate was always subtracted from each test $O D$ value.

\section{SEM Evaluation}

The specimens were fixed in $2.5 \%$ glutaraldehyde solution in $1 \mathrm{M} \mathrm{Na}$ cacodylate buffer for 24 hours. Then they were rinsed in $1 \mathrm{M} \mathrm{Na}$ cacodylate for 30 minutes, dehydrated in the graded series of ethanol $(70,80,90$, and 100 for 15 minutes each) and in freon overnight. Finally, they were dehydrated with $\mathrm{CO}_{2}$ in a bomb.*** The specimens were mounted on aluminum stubs, coated with a $20 \mathrm{~nm}$ gold-palladium layer, ${ }^{+\dagger+}$ and blind studied with SEM, using secondary electron imaging, working over a 4-15 kV range and magnification between 25 and $20,000 \times$. A global area of $100 \times 125 \mu \mathrm{m}$ was examined on each specimen. The area was composed of the sum of five 20 $\times 25 \mu \mathrm{m}$ fields randomly selected for each specimen. The following variables were recorded for each field: presence $(=1)$ or absence $(=0)$ of cocci, short rods, and longrods morphotype. The values herein quoted for the global area are cumulative of those observed in the $20 \times 25 \mu \mathrm{m}$ fields. Bacteria density was recorded. The following variables were recorded in each $20 \times 25 \mu \mathrm{m}$ fields: $\leq 30$ (score 1); > $30 \leq 100$ (score 2); > 100 (score 3) bacteria per field. The value computed for each global area was done by the cumulative sum of each score multiplied by the frequency of observation in the area:

$$
\text { bacteria density index }(\mathrm{BD})=\Sigma \text { (no. fields)(score). }
$$

\section{Statistical Analysis}

The Kruskal-Wallis ANOVA one-way test was used for comparison of profilometric variables, since Fisher ANOVA one-way test could not be applied due to the violation of variance homogeneity assumption tested by the Levene test. Fisher ANOVA one-way test and Scheffé post-hoc

\footnotetext{
"IIMultidish 24-well Nunclor Delta Sl, Nunc, Kamstrup, Denmark.

ข96-well Micrometer Plate, Nunc, Kamstrup, Denmark.

"LP 200, Diagnostic Pasteur, Milan, Italy.

***Top Critical Point 30, W. Pabish, Pero, Milan, Italy.

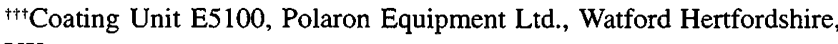
UK.
}

Table 2. Profilometric Analysis of Titanium Disks

\begin{tabular}{lccccc}
\hline & \multicolumn{2}{c}{$\mathrm{Ra}(\mu \mathrm{m})$} & \multicolumn{2}{c}{$\mathrm{Rz}(\mu \mathrm{m})$} \\
\cline { 2 - 3 } \cline { 5 - 5 } Group & Mean & SD & & Mean & SD \\
\hline A & 0.088 & 0.007 & & 1.027 & 0.206 \\
B & 0.201 & 0.006 & & 1.780 & 0.168 \\
C & 2.142 & 0.141 & & 17.546 & 1.498 \\
\hline
\end{tabular}

$\mathrm{SD}=$ standard deviation.

$\mathrm{Ra}$ differs significantly among the groups $(P<0.0001)$. Kruskal-Wallis ANOVA one-way.

$\mathrm{Rz}$ differs significantly among the groups $(P<0.0001)$. Kruskal-Wallis ANOVA one-way.

test were used for evaluation of the biomass variables. The Mann-Whitney U exact-test was used to compare the density bacteria index and the presence of cocci, short and long rods morphotypes observed in groups A, B, and C. The $P$ value was computed by Monte Carlo method. ${ }^{14 \ddagger \ddagger \ddagger}$

\section{RESULTS}

\section{Profilometric and Morphologic Surface Analysis of the Specimens}

A significant difference $(P<0.0001)$ was found among groups $\mathrm{A}, \mathrm{B}$, and $\mathrm{C}$ concerning $\mathrm{Ra}$ and $\mathrm{Rz}$ values (Table 2 ). The polishing procedure used in group $A$ produced the smoothest titanium surface, with small pits and few grooves (Fig. 2A). In contrast, surfaces of group B showed more irregularities mainly due to the grooves caused by the polishing procedure (Fig. 2B). Group C disks showed the roughest surface, characterized by deep pits (Fig. 2C).

\section{Biomass Determination}

The biomass determination was performed in only 5 subjects because of accidental detachment of a specimen in 3 patients. Figure 3 shows the mean and standard deviation of the OD values. The Fisher ANOVA test revealed significant differences $(P<0.05)$ among the groups. Group A hosted significantly less bacteria than group $\mathrm{C}(P<0.001)$. The $P$ values computed by the Sheffè test concerning the comparison group $\mathrm{A} /$ group $\mathrm{B}$ and group $\mathrm{B} /$ group $\mathrm{C}$ were, respectively, 0.069 and 0.692 .

\section{SEM Analysis}

Figure 4 shows the density of bacteria observed in 20 $\times 25 \mu \mathrm{m}$ fields in groups A, B, and C. Group A did not host significantly less bacteria than group $\mathrm{B}$. In contrast, groups $\mathrm{A}$ and $\mathrm{C}$ differed significantly $(P<$ $0.0005)$. Group B was observed to host significantly less bacteria than group $\mathrm{C}(P<0.005)$. Cocci were always observed in the groups. In contrast, the presence

\footnotetext{
‡¥¥SPSS, Chicago, IL.
} 

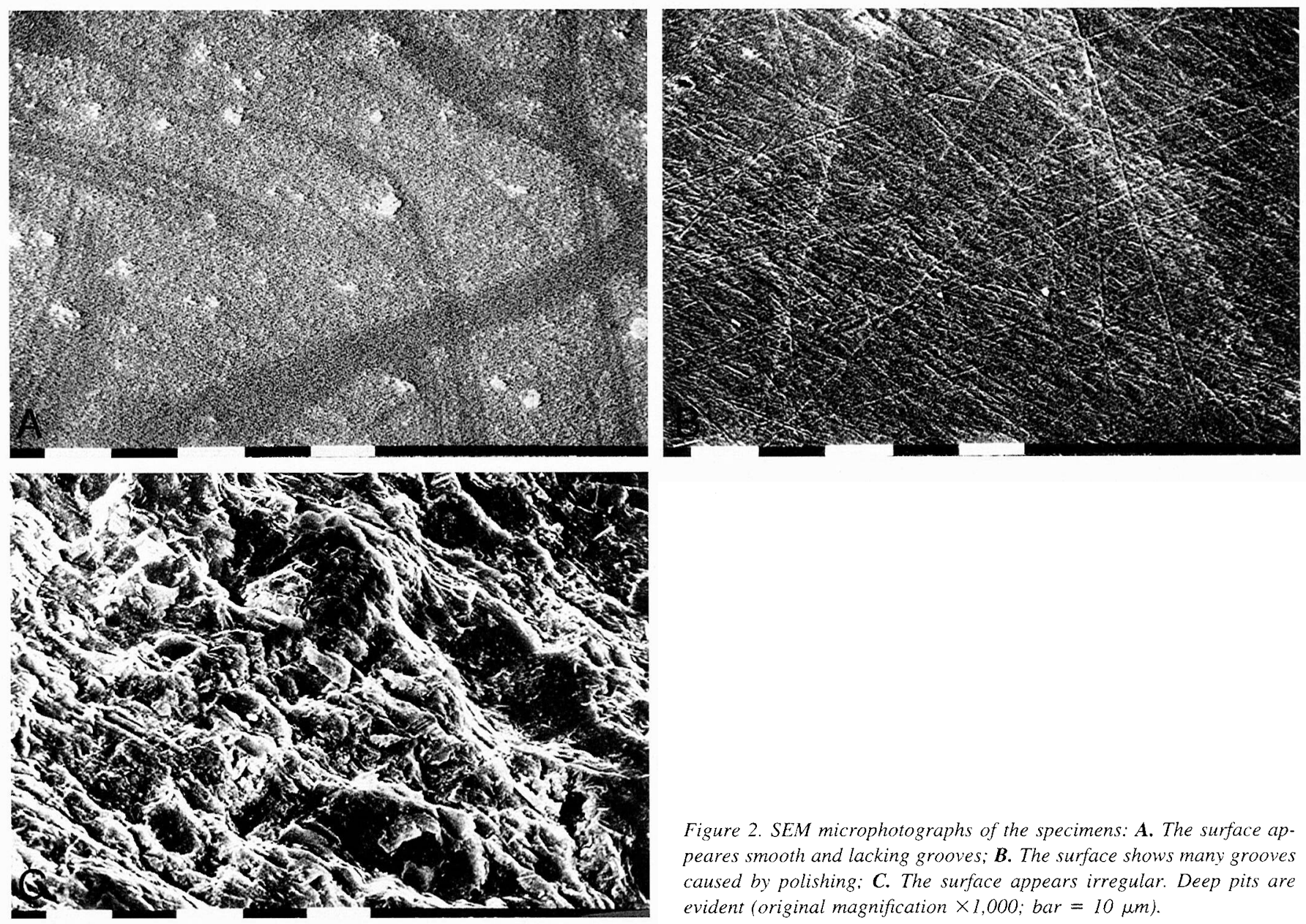

Figure 2. SEM microphotographs of the specimens: $A$. The surface appeares smooth and lacking grooves; $\boldsymbol{B}$. The surface shows many grooves caused by polishing: $\boldsymbol{C}$. The surface appears irregular. Deep pits are evident (original magnification $\times 1,000 ;$ bar $=10 \mu \mathrm{m}$ ).

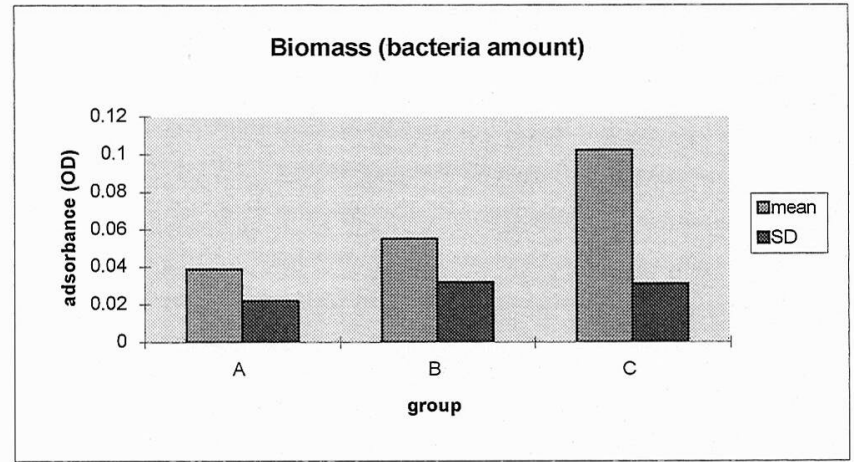

Figure 3. Mean and standard deviation of adsorbance $(O D=$ optical density) among the groups. Fisher ANOVA analysis revealed significant differences between groups $A$ and $C(\mathrm{P}<0.05)$. The $\mathrm{P}$ values computed by Scheffè test were 0.069 for comparison group A/group B, and 0.692 for comparison group B/group C. $S D=$ standard deviation.

of short rod morphotype was different among the groups. The long rod morphotype differed significantly between groups A and $\mathrm{C}(P<0.05)$ and between group $\mathrm{B}$ and $\mathrm{C}$ with $P$ value close to significant level $(P=<$ 0.08) (Table 3). Group A harbored few bacteria limited to cocci morphotypes, localized at the base of concavities caused by the polishing procedure (Fig. 5). No

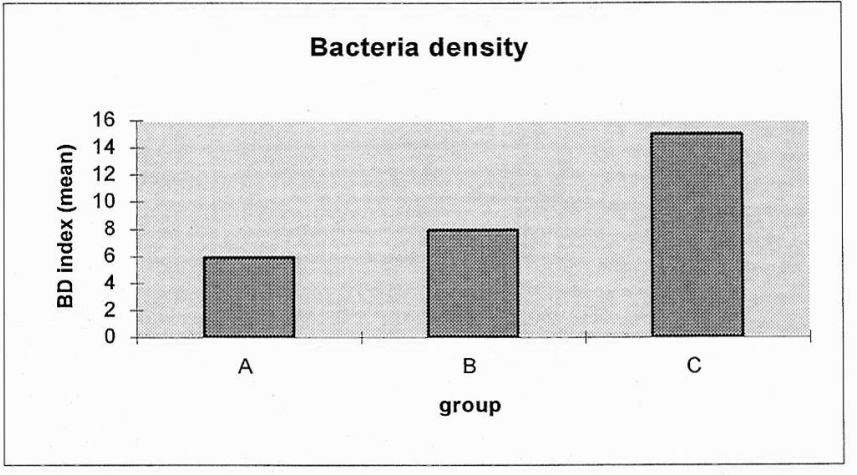

Figure 4. Bacteria density index in the groups. $B D$ index $=$ bacterial density index calculated as $\Sigma$ (no. fields)(score). Comparison between group A/group $B$ not significant $(\mathrm{P}>0.05)$, group A/group $C(\mathrm{P}<$ $0.0005)$, group B/group $C(\mathrm{P}<0.005)$. Mann-Whitney $U$ exact-test (Monte Carlo method).

short and long rods and only a few bacterial aggregations were detected. Group B specimens were observed to harbor more bacteria frequently attached to organic pellicle than group A (Fig. 6). Short and long rods, horizontally arranged, were observed. Group C exhibited the most colonized surfaces. Cocci and bacillary forms were predominant in this group of specimens. 
Table 3. Presence of Cocci and Short and Long Rods

\begin{tabular}{lccc}
\hline & \multicolumn{3}{c}{ Bacterial Morphotype } \\
\cline { 2 - 4 } Group & \% Cocci & \% Short Rods & \% Long Rods \\
\hline A & 100 & 0 & 0 \\
B & 100 & 32 & 2.5 \\
C & 100 & 88 & 32 \\
\hline
\end{tabular}

Data are summarized as mean percentage of observation of morphotypes and bacterial aggregations; statistical differences were computed by Mann-Whitney $U$ exact test using the mean rank. $\mathrm{P}$ values were computed by Monte Carlo method. Significant differences as regards the short rods between groups $A$ and $B(\mathrm{P}<0.05)$, groups $A$ and $C(\mathrm{P}<$ $0.05)$ and groups $B$ and $C(\mathrm{P}<0.05)$. Significant differences as regards the long rods between groups $A$ and $C(\mathrm{P}<0.05)$; comparison between groups $B$ and $C(\mathrm{P}<0.08)$.

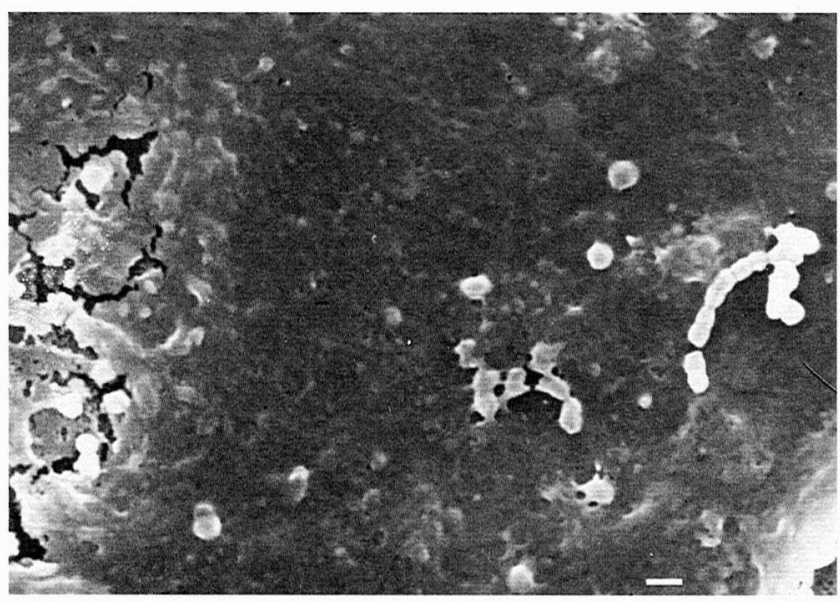

Figure 5. Group A. Few cocci are visible on the surface (original magnification $\times 4,500$; bar $=I \mu \mathrm{m})$.

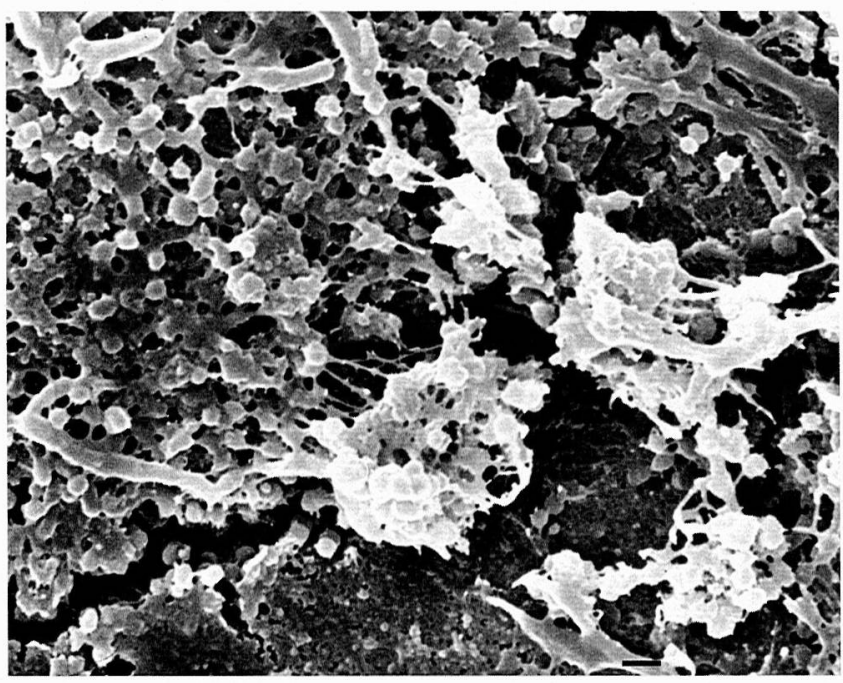

Figure 6. Group B. The surface is colonized by a monolayer of cocci and bacillary forms (original magnification $\times 4,500$; bar $=1 \mu \mathrm{m}$ ).

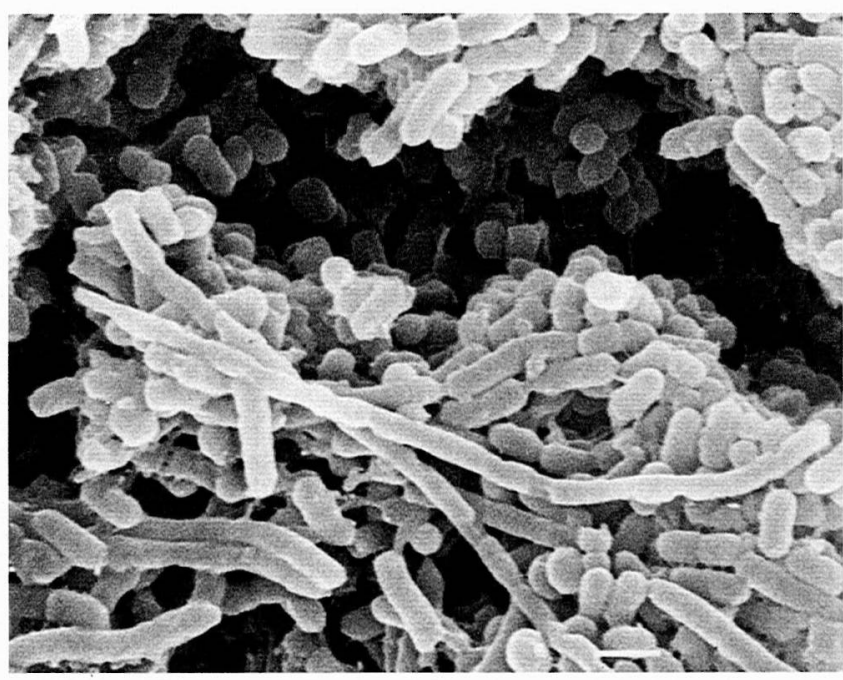

Figure 7. Group C. A thick biofilm composed of cocci, and short and long rods colonizes the surface (original magnification $\times 5,000$; bar $=$ I $\mu \mathrm{m})$.

Long rods were also detected (Fig. 7). A thick organic pellicle was sometimes observed. Bacteria were always observed aggregated in group $\mathrm{C}$.

\section{DISCUSSION}

Osseointegrated titanium dental implants have been proven to provide highly reliable restoration of function in totally and partially edentulous patients over many years of follow-up. ${ }^{15-19}$ Despite encouraging results, much attention has been devoted to the etiology of implant failure. Bacterial plaque colonization was recognized as one of the main factors influencing the success rate of oral implants. ${ }^{11}$ Several studies have pointed out the physicochemical properties of the implant surface as an important factor in promoting colonization. Surface-free energy, ${ }^{9.20 .21}$ roughness ${ }^{22}$ and the presence of specific molecules adsorbed from the saliva onto the titanium surface ${ }^{23}$ are suggested to promote colonization. In particular, surface roughness increases plaque colonization by several mechanisms, which include an increase in the global area available for colonization and the sheltering effect of irregularities, which protect the bacteria from the removal forc$\mathrm{es}^{22}$ and, at the same time, allow them to establish a less reversible binding with the surface. Surface roughness seems to be particularly relevant for early bacterial colonization. It was observed to be prominent with respect to surface-free energy, ${ }^{10}$ and it influences the number and the sequence rate of appearance of the bacteria species with similar modalities in supra and in subgingival areas. ${ }^{24.25}$ Plaque accumulation starts at the level of pits and grooves ${ }^{26}$ and the sequence of appearance is usually cocci, rods, filamentous morphotypes, fusiforms, spirochetes (subgingivally), and bacterial aggregations such as corncobs and test-tube brushes. ${ }^{27}$ The effect of roughness seems to be reduced over time. ${ }^{28}$ 
The different composition of materials only slightly affects plaque colonization. Differences in the amount of adherent plaque are observed in various materials ${ }^{24}$ and tissues. ${ }^{27-29}$ Titanium has been observed to inhibit plaque growth in vitro, particularly in the early stages, probably due to the antimicrobial effect of metal ion release. ${ }^{30}$ However, the amount of early plaque colonization seems to be related more to the roughness degree than to material composition. ${ }^{24}$ The relationship between surface roughness and plaque colonization has been widely studied as a side effect of professional or habitual hygiene procedures. ${ }^{31}$ The surface of the implant abutment, as provided by the manufacturer, has also been observed to be regular $^{32}$ and it could, therefore, be potentially plaque retentive. ${ }^{22}$ However, improvement of surface polishing at baseline has received less attention than the maintenance protocols planned to avoid damage to the titanium surface.

The present investigation examined the relationship between three degrees of surface roughness, obtained by experimental surface finishing procedures of implant titanium, and the amount of supragingival plaque colonization observed after 24 hours. The bacterial morphotypes were also investigated. The surface modification procedures produced different surface morphology and roughness. Particularly in group $\mathrm{A}$, the mean $\mathrm{Ra}$ and $\mathrm{Rz}$ values were 2 to 7 times lower than those reported for transgingival and abutment components of the most common commercial oral implants. ${ }^{32}$ The surface roughness of group B was very similar to that reported for the latter.

The amount of bacterial plaque adhering to the titanium surface was shown to be directly dependent on the roughness by biomass determination as well as by SEM observation, in accordance with previous studies performed with microscopic analysis ${ }^{24.25}$ or microbiological cultures. ${ }^{22}$ In addition, the SEM observations in our study provide information about the degree of bacterial plaque maturation, with particular regard to pioneers colonization phenomenon. In group A, fewer bacterial cells were observed than in the other groups and were limited to cocci morphotypes. Colonization was observed to be localized over badly polished areas. It is noteworthy that the amount of bacteria observed after 24 hours in group A seemed to be less than reported by other studies on implant collars, plasma sprayed titanium, ${ }^{25}$ other materials ${ }^{22}$ and dental tissues. ${ }^{27-29}$ We suggest that the observed results could be due to the inhibition of the phase of bacterial adhesion. The surface-finishing degree achieved in group A did not allow bacteria to establish a firm adhesion to the contaminated titanium surface. Plaque maturation is observed to be related to the roughness degree. Cocci have been observed as pioneer species primarily involved in bacterial colonization. Rods appear secondarily, frequently aggregated with cocci, and they can be considered as an indicator of advanced stages of matu- ration. Short and long rods were never detected in group A disks. In contrast, they were always observed in group $\mathrm{C}$ and were aggregated and multilayered. It is evident that the polishing degree achieved in group A strongly hindered bacterial colonization, limiting it to coccoid forms, usually non-pathogenic with respect to peri-implant tissues disease.

Although these results were obtained using a 24-hour supragingival plaque colonization model, they may be clinically relevant because the first bacterial layers in contact with a surface determine the strength of adhesion of the whole biomass to the surface itself. Moreover, the amount of early plaque colonization and the sequence of bacterial species appearance over the titanium surface has been suggested to be similar in supra- and subgingival regions, ${ }^{25}$ because the mechanism of bacterial adhesion is supposed to be the same in both environments. Therefore, it is rational to suppose that finishing degree of the titanium surface achieved in group A might hamper subgingival colonization as it did in the supragingival condition.

Our results demonstrated that a titanium finish with $\mathrm{Ra}$ $\leq 0.088$ and $\mathrm{Rz} \leq 1.027 \mu \mathrm{m}$ strongly hampered plaque colonization after 24 hours. We suggest that a similar surface-finishing degree should characterize the surface of trans-gingival and healing implant components in order to minimize plaque colonization and aid in good healing and health to peri-implant tissues.

\section{Acknowledgments}

The study was supported by the Italian Research Council (C.N.R.) grant 93.01549.CT11.

\section{REFERENCES}

1. Schonfeld SE. Oral microbial ecology. In: Slots J, Taubman MA, eds. Contemporary Oral Microbiology and Immunology. St. Louis: The CV Mosby Company; 1992:267.

2. Listgarden MA. Structure of microbial flora associated with periodontal health and disease in man. $J$ Periodontol 1976;47:1-18.

3. Leonhartd $\AA$, Berglundh T, Ericsson I, Dalhen G. Putative periodontal pathogens on titanium implants and teeth in experimental gingivitis and periodontitis in beagle dogs. Clin Oral Impl Res 1992;3:112-119.

4. Eke PI, Braswell L, Fritz M. Succession of putative peri-implant pathogens after root-form and plate-form implant placement in partially dentate adult monkeys. J Periodont Res 1995;30:88-96.

5. Lang NP, Bragger U, Walther D, Beamer B, Kornman KS. Ligatureinduced peri-implant infection in cynomolgus monkey. I. Clinical and radiographic findings. Clin Oral Impl Res 1993;4:2-11.

6. Quirynen M, Bollen CML. The influence of surface roughness and surface-free energy on supra and subgingival plaque formation in man. A review of the literature. $J$ Clin Periodontol 1995;22:1-14.

7. Gibbons RJ. Bacterial adhesion to oral tissues: a model for infection disease. J Dent Res 1989;68:750-760.

8. Cisar JO. Coaggregation reaction between oral bacteria: studies of specific cell-to-cell adherence mediate by microbial lectins. In: Genco RJ, Merghenhagen SE, eds. Host-Parasite Interaction in Periodontal Disease. Washington DC: American Society for Microbiology Publications; 1982:121-131.

9. Absolom DR, Lamberti F, Policova Z, Zingg W, van Oss CJ, Neu- 
mann AW. Surface thermodynamics of bacteria adhesion. Appl Environ Mocrobiol 1983;46:90-97.

10. Quirynen M, Marechal M, Busscher HJ, Weerkamp AH, Darius PL, van Steenberghe D. The influence of surface-free energy and surface roughness on early plaque formation. An in vivo study in man. $\underline{J}$ Clin Periodontol 1990;17:138-144.

11. Mombelli A, Lang NP. Microbial aspects of implant dentistry. Periodontol 2000 1994;4:74-80.

12. Löe H, Silness J. Periodontal disease in pregnancy. I. Prevalence and severity. Acta Odontol Scand 1963;21:533-551.

13. McDowell SG, An YH, Draughn RA, Friedman RJ. Application of a fluorescent redox dye for enumeration of metabolically bacteria on albumin-coated titanium surfaces. Lett Appl Microbiol 1995;21: $1-4$.

14. Senchaudhuri P, Mehta RC, Patel NR. Estimating exact $p$ values by the method of control variates, or Monte Carlo rescue. J Am Stat Assoc 1995;90:640-648.

15. Adell R, Lekholm U, Rockler B, Brånemark P-I, Jemt T. A longterm follow-up study of osseointegrated implants in the treatment of totally edentulous jaws. Int J Oral Maxillofac Implants 1990;5: 347-359.

16. Zarb GA, Schmitt A. The longitudinal clinical effectiveness of osteointegrated dental implants: the Toronto study. 3. Problems and complications encountered. J Prosthet Dent 1990;64:185-194.

17. Jemt $\mathrm{T}$, Lekholm U. Implant treatment in edentulous maxillae: a 5-year follow-up report on patient with different degree of jaw resorption. Int J Oral Maxillofac Implants 1995;10:303-311.

18. Albrektsson T, Dalhen G, Enbom L, et al. Osseointegrated oral implants. A Swedish multicenter study of 8139 consecutively inserted Nobelpharma implants. J Periodontol 1988;59:287-296.

19. Jemt $\mathrm{T}$, Lekholm U, Adell R. Osseointegrated implants in the treatment of partially edentulous patients: a preliminary study of 876 consecutively placed fixtures. Int $\mathrm{J}$ Oral Maxillofac Implants 1989;4:211-217.

20. Busscher HJ, Uyen MHMJC, Weerkamp AH, Postma WJ, Arends J. Reversibility of adhesion of oral streptococci to solids. FEMS Microbiol Lett 1986;35:303-306.

21. Van Dijk J, Herkströter F, Busscher H, Weerkamp A, Jansen H,
Arends J. Surface-free energy and bacterial adhesion. An in vivo study in beagle dogs. J Clin Periodontol 1987;14:300-304.

22. Quirynen M, Van der Mei HC, Bollen CML, et al. An in-vivo study of the surface roughness of implants on the microbiology of supraand subgingival plaque. $J$ Dent Res 1993;72:1304-1309.

23. Wolonsky L, de Camargo P, Erad J, Newman M. A study of an in vivo attachment of Streptococcus sanguis and Actinomyces viscosus to saliva treated titanium. Int J Oral Maxillofac Implants 1989;4: $27-31$.

24. Siegrist BE, Brecx MC, Gusberti FA, Joss A, Lang NP. In vivo early human dental plaque formation on different supporting substances. A scanning electron microscopic and bacteriological study. Clin Oral Impl Res 1991;2:38-46.

25. Gatewood RR, Cobb CM, Killoy WJ. Microbial colonization on natural tooth structure compared with smooth and plasma-sprayed dental implant surfaces. Clin Oral Impl Res 1993;4:53-64.

26. Lie T. Morphologic studies on dental plaque formation. Acta Odontol Scand 1979;37:73-85.

27. Nyvad B, Fejerskov O. Transmission electron microscopy of early microbial colonization of human enamel and root surfaces in vivo. Scand J Dent Res 1987;95:297-307.

28. Nyvad B, Fejerskov O. Scanning electron microscopy of early microbial colonization of human enamel and root surfaces in vivo. Scand J Dent Res 1987;95:287-296.

29. Carrassi A, Santarelli G, Abati S. Early plaque colonization on human cementum. J Clin Periodontol 1989;16:265-267.

30. Joshi RI, Eley A. The in vitro effect of a titanium implant on oral microfiora: comparison with other metallic compaunds. J Oral Microbiol 1988;27:105-107.

31. McCollum J, O'Neal RB, Brennar WA, Van Dyke TE, Horner JA. The effect of titanium implant abutment surface irregularities on plaque accumulation in vivo. J Periodontol 1992;63:802-805.

32. Quirynen M, Bollen CML, Willems G, van Steenberghe D. Comparison of surface characteristics of six commercially pure titanium abutments. Int J Oral Maxillofac Implants 1994;9:71-76.

Send reprint requests to: Lia Rimondini, via Procaccini 16/2, 40129 Bologna, Italy. (e-mail: pib1431@iperbole.bologna.it)

Accepted for publication November 8, 1996. 